\title{
Erratum to: Restoring habitat and cultural practice in Australia's oldest and largest traditional aquaculture system
}

\author{
Denis Rose · Damein Bell - David A. Crook
}

Published online: 17 October 2016

(C) Springer International Publishing Switzerland 2016

Erratum to: Rev Fish Biol Fisheries (2016)

26:589-600

DOI 10.1007/s11160-016-9426-1

\begin{abstract}
Although this article was published in the previous journal issue, it is part of the special issue "Indigenous participation and partnerships in aquatic research and management" edited by David A. Crook, Michael M. Douglas, Alison J. King and Stephen Schnierer for the journal of Rev Fish Biol Fisheries. Please see volume 26 pages 589-600 for this paper.
\end{abstract}

The online version of the original article can be found under doi:10.1007/s11160-016-9426-1.

D. Rose · D. Bell

Gunditj Mirring Traditional Owners Aboriginal

Corporation, PO Box 216, Heywood, VIC 3304, Australia

D. A. Crook $(\bowtie)$

Research Institute for the Environment and Livelihoods, Charles Darwin University, Darwin, NT 0909, Australia

e-mail: david.crook@cdu.edu.au 